\title{
11 Race, Education, and Democracy
}

\author{
Scott L. Pratt
}

At the center of what it means to be democratic is the commitment to equality. This commitment emerges in our talk about public policies, in our talk about careers and economic opportunity, and in our talk about education. In light of equality, we say, we must overlook differences among individuals in order to treat everyone as the same. When the so-called playing field is not "level," we think it undermines equality and ought to be changed so that the ideal of equality can be more nearly achieved. At the same time, democracy seems to call for a parallel commitment to maintaining the distinctiveness of individuals. In this case, public policies, economic processes, education, and so on are thought about in a way that supports individual development and opportunity. Difference, in this case, is a goal, not a hindrance, and is what makes the level playing field worth having. This tension within the context of a democratic society is manifest as well in its institutions, including those most central to the education of a democratic citizenry-public universities. Such institutions capture their democratic commitments in a variety of policy statements and programs and make the tension most clear in their overall mission statements. My own institution, the University of Oregon, makes the commitments to equality and distinctive individuals central to the education we provide when we say in our mission that the university is dedicated to "the principles of equality of opportunity and freedom from unfair discrimination for all members of the university community and an acceptance of true diversity as an affirmation of individual identity within a welcoming community."

The mission statement, however, complicates the matter. Not only does it affirm the commitment to equality and the importance of individuals, but it also asks for an acceptance of "true diversity." At one level, this is to say no more than I have said-democracy and, by extension education in a democracy, ought to foster individual distinctiveness, "true diversity." But the moment one starts to talk about individual distinctiveness in relation to differences of gender or race there is a problem. Doesn't recognition of race difference, for example, undermine equality by highlighting an aspect of individuals that cannot be shared by all? Not everyone, of course, is white nor is everyone black, and, given our usual understanding of being white or black, they can never be. At the same time, the recognition of race difference seems to undermine the commitment to individuals as well. To emphasize individuality is to emphasize what makes 
a person different from everyone else, but to recognize that someone is African American or that someone is white is to fail to recognize them as individuals-as Peter or Patricia-and instead to recognize them for the groups to which their skin color connects them. In fact, if racism is understood as practices which violate our commitments to equality and individuality because of race, then it seems that recognizing race is itself a form of racism. In light of this sort of argument, some people, black and white, are ready to set aside the notion of race because it is an obstacle to ending racism. ${ }^{2}$

At the same time, others argue that the only way to solve the problem of racism and other forms of oppression based on difference is to address the problem on its own terms. The response to discrimination against blacks in hiring or college admissions is something that calls for the identification of people's races in order to change the practices of discrimination. One cannot argue that there are no black faculty members in a philosophy department or black students in an entering class unless one is willing to identify the racial backgrounds of the faculty and students. We cannot even get a sense of whether or not things are changing without systematically recognizing racial difference. To do so from the perspective of democracy, however, is to be in tension with the commitments to equality and individuality. Again, the recognition of race runs the risk of becoming identified with racism.

\section{Individuality and Diversity}

Once race and racism are taken together, it becomes hard to see how race difference can fit in the context of education in a democracy. For students of color, the identification of race and racism devalues and excludes a crucial aspect of experience-because it connects racial identity with the acknowledged evil of racism. For white students, the connection amounts to permission to disregard the role and construction of race and so to unwittingly perpetuate the oppression that we are otherwise quick to acknowledge in the process and institutions of education.

For most of us, however, the "reasoned" argument does not persuade. Even if our commitments to equality and individuality seem necessarily at odds with our commitment that race matters, we nevertheless remain committed to each. The problem, I want to suggest, is not that any of these commitments ought to be suspended, but that they need to be rejoined with a different conception of identity and humanity. ${ }^{3}$ Rather than viewing human beings as individuals accidentally born into various circumstances with bodies that aren't relevant to our humanity, we need to reconceptualize human beings as fundamentally embodied, and so gendered, racial, and historical beings. To deny the importance or relevance of race in our social relations, or to think that by acknowledging race we have only racism, is to misconceive humanity.

The source of the alternative view I will propose is found in the work of W. E. B. Du Bois. When, in 1903, Du Bois declared that the "problem of the 
20th century is the problem of the color-line," he did not also declare that the solution was its elimination. Rather, Du Bois argued for the conservation of races and, in that sense, the preservation of the color line, reconstructed in a way that recognized that talk of race, thinking about race, identifying by race, is not fundamentally racist but fundamentally a source of enrichment, insight, and growth for individuals and for the wider community. This approach, grounded in pragmatic pluralist commitments like those of William James, Jane Addams, and John Dewey, aimed at transformation of American society by offering an alternative to the "melting pot" on one hand, and racial apartheid on the other.

In his controversial 1897 paper "The Conservation of Races," Du Bois argued that races be conserved on the grounds that each race had a contribution to make to humanity as a whole. In this light, he argued that African Americans, as part of the African or black race, had a responsibility to help maintain racial distinctiveness even in the oppressive world of American apartheid. On this view, to talk about race is not to be racist in the usual sense, but rather to participate in a dialogue that helps to develop a kind of distinctiveness indispensable to the character and development of human beings. Rather than undermining democratic commitments, Du Bois aimed to provide a means by which democracy would actually be supported by the recognition of race. Under this reconstructed notion of race, democracy itself is transformed from a society that emphasizes the priority of individuals of the sort presented by J. S. Mill and classical liberal thinkers, to a society in which individuals share priority with groups. Du Bois says, "the history of the world is the history, not of individuals, but of groups, not of nations, but of races, and he who ignores or seeks to override the race idea in human history ignores and overrides the central thought of all history" (Du Bois 1897, p. 817).

In order to make sense of this transformed notion of democracy, we must understand the relationship between individuals and races. Du Bois defines a race as "a vast family of human beings, generally of common blood and language, always of common history, traditions and impulses, who are both voluntarily and involuntarily striving together for the accomplishment of certain more or less vividly conceived ideals of life" (Du Bois 1897, p. 817). The definition points out three important features of Du Bois's notion of race. First, the notion that race is "a vast family ... generally of common blood and language" suggests that race depends in part on aspects of ourselves that come to mind when we talk about family resemblance. From one angle, it means that a similarity of look and speech more or less places individuals in relation to each other. From another angle the idea of a vast family makes the connection among people depend upon our most intimate physical and emotional connections-our bodies, our earliest memories, our expected inheritances. In effect, race is physically in the bodies of individuals, an inheritance of the most direct kind. Second, the idea that race is a matter of a shared or common history suggests that race depends not just on the connection between members of the "family," but also upon the shared story of its own development and its struggles, misfor- 
tunes, failures, and successes in interactions with other groups. Third, the idea that a common "voluntary and involuntary striving" asserts that races are not only inherited bodies and histories, but are also in part joined by visions of a shared but distinctive future.

Some current theorists of race try to reduce race to questions of morphological differences. From this perspective, the lack of a definitive biological basis for the differences then supports arguments that race is a meaningless category. ${ }^{5}$ Other race theorists, especially in light of the problems that follow from reliance on morphological differences, reduce the idea of race to a matter of culture or ethnicity, preserving racial distinctiveness but converting it to a set of beliefs and practices that can be shared by all. ${ }^{6}$ Du Bois will not permit either a reduction of race to physical difference or a reduction of race to ethnicity. He says, "But while race differences have followed mainly physical race lines, yet no mere physical distinctions would really define or explain the deeper differences-the cohesiveness and continuity of these groups. The deeper differences are spiritual, psychical, differences-undoubtedly based on the physical, but infinitely transcending them" (Du Bois 1897, p. 818).

From this perspective, races as groups are not sharply defined genetic (or ancestral) groups, or communities of individuals who share only a particular set of established customs and beliefs, or even more or less random groups joined in the face of particular political or economic need. They are ongoing, distinctive groups of individuals who have a richly shared past-in physical inheritance, cultural practices, and remembered history. Since Du Bois, like James and Dewey, believes that what we can do depends upon what we bring to the process, racial distinctiveness understood in this complex way has a direct bearing on the things that people produce, the ideas they have and share, their art, literature, ambitions, and constraints. Taken together these distinctive productions dependent on a racial past, present, and future are what Du Bois calls racial "gifts." Viewed from the standpoint of human community, these gifts amount to the means by which human beings grow as individuals and by which human groups develop, innovate, and enrich each other. To lose such "gifts" reduces the potential for human flourishing; to conserve them is to foster growth. Racial "gifts," then, justify the conservation of races. Du Bois concludes, "We believe that the Negro people, as a race, have a contribution to make to civilization and humanity, which no other race can make... . We believe it the duty of Americans of Negro descent, as a body, to maintain their race identity until [the] mission of the Negro people is accomplished, and the ideal of human brotherhood has become a practical possibility" (Du Bois 1897, p. 825)?

For Du Bois, the features that define race-embodiment, social history, aspirations for the future-also define individual identity. In this sense the broad characteristics of racial difference are in fact only manifested in the lives of individuals. Du Bois suggests this notion of individual identity in his famous description of African American identity in his collection of essays The Souls of Black Folk: 
After the Egyptian and Indian, the Greek and Roman, the Teuton and Mongolian, the Negro is a sort of seventh son, born with a veil, and gifted with second-sight in this American world-a world which yields him no true self-consciousness, but only lets him see through the revelation of the other world. It is a peculiar sensation, this double-consciousness, this sense of always looking at one's self through the eyes of others, of measuring one's soul by the tape of a world that looks on in amused contempt and pity. One ever feels his two-ness-an American, a Negro; two souls, two thoughts, two unreconciled strivings; two warring ideals in one dark body, whose dogged strength alone keeps it from being torn asunder.

(Du Bois 1903, pp. 364-65)

Notice the elements of the description. The body serves as the necessary ground in terms of which one must understand oneself. The body is also what is seen by others so that one is not only what one sees from one's own eyes, but one is in crucial ways almost literally what others see. Beyond the body and the self as seen by others, one is also a self of "strivings" and ideals which take one beyond one's present physical moment to a moment of self-definition. This definition of one's self is constrained by the physical and social, but is not fully determined by it. Du Bois continues (bracketing his gendered terms):

The history of the American Negro is the history of this strife,-this longing to attain self-conscious manhood, to merge his double self into a better and truer self. In this merging he wishes neither of the older selves to be lost. He would not Africanize America, for America has too much to teach the world and Africa. He would not bleach his Negro soul in a flood of white Americanism, for he knows that Negro blood has a message for the world. He simply wishes to make it possible for a man to be both a Negro and an American, without being cursed and spit upon by his fellows, without having the doors of Opportunity closed roughly in his face. (365)

Identity is to be understood as an embodied consciousness where individuals are a complex of perspectives, histories, and aspirations joined together in a living and active-that is, a striving-body.

If I ask who I am, I cannot properly answer "a thinking thing" in the manner of Descartes, nor "a material thing" in the manner of contemporary materialists like Paul Churchland, or even "a biological thing" in the manner of some "naturalists." For Du Bois, I am this body and material location in relation to characteristic material things (looking a certain way, wearing certain clothes, living in a certain place, and so on). I am also this social creature-with a set of roles and social relations (a teacher, a father, and a white man). And I am someone with certain dispositions and aspirations as well. I cannot be reduced to any of these things, nor can any of these be set aside as mere epiphenomena irrelevant to who I "really" am. This body constrains and enables social relations; these social relations constrain and enable these aspirations; these aspirations constrain and enable this body and material location. William James, with whom Du Bois studied at Harvard, had a similar conception of the self, and, in a re- 
sponse to those who would define selves as "separate souls" free of embodied constraints, James writes, "Unless our consciousness were something more than cognitive, unless it experienced partiality for certain of the objects, which, in succession occupy its ken, it could not long maintain itself in existence; for, by an inscrutable necessity, each human mind's appearance on this earth is conditioned upon the integrity of the body with which it belongs, upon the treatment which that body gets from others, and upon the spiritual dispositions which use it as their tool, and lead it either towards longevity or to destruction" (James 1892, p. 194). ${ }^{8}$

Du Bois complicates the self that James proposes by recognizing that embodied selves come to be in a historical moment such that distinctive morphological differences play an overt role in how people sort themselves and others. The resulting groupings that at first depend upon overt physical differences become the contexts in which individuals develop other features (such as social practices and future aspirations) which eventually are labeled as racial differences. Races, as a result, are natural but contingent historical developments, and although physical difference plays a role in this development, it is by no means a sufficient condition for race identity nor a wholly determinant element in human lives. In "The Conservation of Races" he gives a genealogy of race that emphasizes this point:

Although the wonderful developments of human history teach that the grosser physical differences of color, hair, and bone go but a short way toward explaining the different roles which groups of men have played in Human Progress, yet there are differences-subtle, delicate and elusive, though they may be-which have silently but definitely separated men into groups. While these subtle forces have generally followed the natural cleavage of common blood, descent and physical peculiarities, they have at other times swept across and ignored these. (Du Bois 1897 , pp. 816-17)

When we consider "real history," as Du Bois says, we find the "widespread, nay, universal, prevalence of the race idea, the race spirit, the race ideal" (817). It is not, however, a prevalence that has in general blocked human progress and development, but has been a way in which diversity has flourished to the benefit of the widest human community.

This is not to say that the conception of race in general or of what it means to be black or white has not changed over time, but it does suggest that race and races are not just the product of prejudice and exclusion. Rather, race emerges first as an aspect of life in a physically diverse world in which bodily differences become connected with differences of intimate relations, interests, dress, ceremonial forms, beliefs, aspirations, and so on. That race has come to be associated with virulent prejudice, violence, and dehumanization has as much to do with the attempt to eliminate race and its associated diversity in favor of a single way of looking, thinking, and acting. Given the close connection between racial differences and the ways in which people see themselves and others, the attempt 
to overlook race does not enhance the individual as an individual, but rather undermines her. To set aside race is really only to suppress distinctiveness in favor of some other ways of thinking and being which, from Du Bois's naturalistic perspective, can only have been the product of some particular racial history. The result is that the body, social location, and aspirations of individuals not of the dominant race are seen as deficiencies and failings that must be overcome. To live in such an environment and attempt to respond to the demands to not be African American or Native American or Asian or Latin American is itself a form of physical and psychological violence. As Du Bois puts it, under such circumstances "The price of culture is a Lie" (Du Bois 1903, p. 504).

The idea of individual identity Du Bois proposes initially focuses on conceptions of race, but the general approach which identifies the importance of one's physical and material place, one's social relations, and one's aspirations provides a general way to respond to other sorts of difference. Du Bois himself recognized that gender and economic class mark two other important kinds of "family resemblance" that are, in part, constitutive of one's self in the context of twentieth-century America. Despite the real and distinctive perspectives possible from different gender and class "locations," the dominant thinking advocates that the same process of elimination demanded for race is demanded for these perspectives. Even though women, on this view, have distinctive embodied perspectives that connect with contributions to the wider community, knowledge and insight classified as "women's" can only be ignored. Even though the evils of poverty are best understood from the perspective of those suffering, such perspectives must, from the dominant point of view, be set aside in favor of the perspective imposed by those most distant from a life of poverty. In each case Du Bois argues that the distinctiveness of these embodied lives must be promoted rather than overlooked and suppressed in a way that will ameliorate suffering and lead to grow th. ${ }^{9}$

Race, then, for Du Bois becomes a transformative notion. By focusing on the history and experience of race, he transforms James's notion of individual identity largely formed from the perspective of a privileged white academic to a broader notion of identity that recognizes the categories that people in racialized societies actually use to organize their own lives. In this way $\mathrm{Du}$ Bois is able to avoid arguing that race is an a priori category in which humanity must be understood, and instead argue for its status as a kind of organizing ideal. This ideal, he argues in the celebrated first chapter of The Souls of Black Folk, emerges in particular as one of the gifts of "Black Folk" to humanity. He says:

Work, culture, liberty-all these we need, not singly but together, not successively but together, each growing and aiding each, and all striving toward that vaster ideal that swims before the Negro people, the ideal of human brotherhood, gained through the unifying ideal of Race; the ideal of fostering and developing traits and talents of the Negro, not in opposition to or contempt for other races, but rather in large conformity to the greater ideals of the American Republic, in order that some day on American soil two world-races may give each to each those characteristics both so sadly lack. (Du Bois 1903, p. 370) 


\section{Equality and Difference}

I began this paper by proposing that education in a democracy is faced with a problem about the role of race in learning. It seemed that if we systematically recognize race we apparently undermine our democratic commitments to equality and individuality. Du Bois, I think, gives us another perspective. If we take up his perspective, then it appears that our identities are only human but depend as well on how we look, our material circumstances, our histories, and our dreams. Race as a term captures the aspect of our selves-developed historically-that identifies the importance of certain physical, material, social, and cultural characteristics. If this is so, then the recognition of race does not undermine our commitment to individuality at all, but rather is necessary to it. That such recognition locates individuals as members of groups not only does not make them less individual, but grants standing to groups as well. When we recall the university commitment to "true diversity," Du Bois gives us a conceptual standpoint from which such diversity can be promoted.

Equality is another matter. It appears that our commitment to the recognition of racial difference is bound to undermine the notion of equality at every turn. Yet, by reconstructing the notion of individual identity, $\mathrm{Du}$ Bois also reconstructs the notion of equality. In a 1929 debate on whether or not African Americans should be "encouraged to seek cultural equality," Du Bois argues against understanding equality as "absolute identity or similarity" among cultures, but rather to understand equality as an expectation that each culture has the potential to make an equally valuable "gift" to the wider community (Du Bois 1929, pp-47-50). Following this approach, equality among individuals is not a comparison between the circumstances of individuals, but rather an assessment of the circumstances of individuals with respect to their potential to develop their particular "gift" to the community.

An example might be useful. Suppose a person is a talented musician but has no opportunity to develop that talent. Perhaps through some community organization, the musician is provided with music lessons and a tuned piano. From one perspective, some in the community will argue that since another person, a talented painter, is not given music lessons, they are being treated unequally. From Du Bois's perspective, if the painter is in a position to develop her talents and the musician his, then they are equally treated regardless of whether they have "the same" opportunities. Equality is defined with respect to the growth of individuals, not by antecedent or independent standards.

Consider a second example. One objection to bilingual education is that it produces inequality in the learning environment by privileging bilingual students with extra resources and opportunities and denying the same to those who speak English only. Given the approach suggested by Du Bois, bilingual education would be better understood as a response to the particular circumstances and the "gifts" of bilingual students. Contrary to the criticism, Du Bois would find that failure to provide bilingual education or some appropriate alternative would undermine equality by failing to respect the distinctive gifts of 
those students whose language needs are different from the majority. Similar arguments could be made about affirmative action programs and educational opportunity programs. In general, Du Bois reconstructs the notion of equality by shifting the standard from blind comparison to relative comparisons within particular circumstances. ${ }^{10}$

On this approach, a democratic commitment to equality cannot ignore race but, on the contrary, must recognize it as an aspect of the individuals who are to be treated equally. Since one's race negatively and positively supports and constrains what one does, if we are interested in an equality of gifts, we must also be interested in promoting those aspects of life which enable these gifts. Again, from Du Bois's perspective, individuality and now equality in our present time and place demand that we recognize race.

But what are the implications of this approach for the place of race in learning? It is interesting to see that in 1955, shortly after the Brown v. Board of Education Supreme Court decision that reversed the Plessy v. Ferguson decision and established the legal requirement for integrated schools, Du Bois gave a talk in which he made two important observations. First, the Brown v. Board of Education decision was long sought and much needed but would come at a high price. "With successfully mixed schools," he said, African Americans "know what their children must suffer for years from southern white teachers, from white hoodlums who sit beside them and under school authorities from janitor to superintendents, who hate and despise them." These new circumstances will also change how race is conceived: African Americans "must eventually surrender race 'solidarity' and the idea of American Negro culture to the concept of world humanity, above race and nation. This is the price of liberty. This is the cost of oppression" (1955, p. 283). Despite this surrender, however, Du Bois observed that, second, African American culture will persist and must. "It's just one more long battle," he concluded, "but we are ready to fight it" (284). From a vantage point nearly fifty years later we may be able to heed the implicit warning and address the issue of race and learning in a more careful way than through uniform integration, now informed by Du Bois's conceptions of race and identity.

If we follow Du Bois's thinking, it seems clear that race and learning must not be separated, but rather they must be brought together. If we are in part constituted by the contingent developments of racial inheritance and our view of ourselves and others is framed by how we are seen by others in racial terms, then it seems clear that whatever our gifts as teachers and students, they will be realized only in an environment where race plays a role. This conclusion is perhaps not easy for anyone. Taken seriously, it means that the university, for example, ought to take an active role in making itself an environment that promotes "true diversity" in general and racial diversity in particular. For the university, this means a transformation from every perspective: the student population would become more diverse, as would the faculty and the administration. It also means that the university curriculum would change, not only by incorporating an ethnic studies program, but by incorporating opportunities to un- 
derstand racial difference, history, and possibilities across all departments and courses.

The impact of such a change in approach would be most striking, I think, for those of us who are white. The usual fear on everyone's part is that attention to whiteness can lead only to claims of supremacy on one hand and guilt on the other. Both conclusions, I think, extend from a notion of race that Du Bois would have us set aside. In fact, Du Bois was one of the first to theorize publicly and at length about whiteness. His essay in Darkwater, "The Souls of White Folk" (1920), and the chapter of his autobiography Dusk of Dawn, entitled "The White World" (1940), show how his conception of individual identity can make race an issue even for those of us who assume that only other people are racial. From Du Bois's perspective, whiteness, like blackness or brownness or Indianness, combines a range of bodily features, a history of social relations, and aspirations for the future for purposes of conservation as well as criticism and reconstruction.

If race is taken personally, white people would be immediately aware that at least part of who they are is how they-or rather we-are seen by those who understand themselves to be racially different. While we may think that such views of ourselves do not matter, they do, both in what is possible for those of us with "white" bodies and in what is not possible. That we have overlooked these opportunities and constraints is not proof that they do not exist, but rather that we have been so possessed of overconfidence and single-mindedness -perhaps overpossessed of Western philosophy-that we have failed to see what African American, Native American, and Latino and Latina authors have long been saying. In the context of learning, attending to the distinctiveness of our bodies, the histories that have produced them, and their implications for our future is a way to attend to how we are heard and how we listen.

By consciousk placing race into the context and process of learning, white people will also come to notice the ways in which they have been advantaged by social and economic history and how these same relations though transformed in various ways still play an important role in what we teach and what we learn. Once we recognize our whiteness, we recognize as well the way in which we speak with authority and are heard, often without challenge, and sometimes with rage. When we speak in class, we are not speaking as disembodied "human beings" who are defined only by what we have in common with those who are racially different; we are also embodied white people who are what we are because of a history of white prejudice, economic exploitation, and genocide. When a student of color speaks with anger or refuses to speak, it is not just a matter of so-called academic ability, as some would say, but something connected in part to a long history of what we-the student and the teacher-bring to the classroom. When a student of color speaks with rage, it is not, on this view, mere bad behavior, but something grounded in a larger circumstance and must be dealt with, not dismissed.

Finally, the aspirations which make us in part who we are are not separate from how we are viewed by others, from our histories, and from our bodies. 
Aspirations are about what we think possible and, at least as importantly, what we think valuable. We set goals for ourselves in light of what we have come to value and in light of what we believe to be possible for ourselves. One of Du Bois's charges against African Americans is that they had come to value the gifts of white folk but not their own. The problem from the white perspective is that many of us have come to value gifts and futures that are consistent with what we take to be a line of development of what Du Bois called the "childish idea of progress" (Du Bois 1971, p. 64). To value progress is to value "bigger better results always and forever" regardless of the cost. At first glance, in the context of education it may seem that the distinctive aspirations associated with racial difference are best seen as motivating ideas whose only real consequence is in whether one moves forward in a course or toward a degree. Perhaps this is right, but to notice that one's values also structure one's thinking about subject matters and even whether teachers think that a student is successful merits further consideration. When aspirations become dominant and are imposed without regard to the persons on whom they are imposed, even the most "noble" values and aspirations become oppressive. As white teachers, for example, some of us become convinced that the standards of success that we adopt based on our own history are the only standards and are also the ones we ought to instantiate in our students. At times, I would say, such unthinking impositions result only in tragedy. There is, I think, no solace in thinking that such a tragedy is for the best since the unfortunate student was not up to the challenge.

By bringing race and learning together Du Bois would have white educators realize that aspirations and values are as much a part of one's identity as social location and skin color. From the perspective of an educator, this realization should compel us to pay careful attention to the role our aspirations play in the classroom and the extent to which the aspirations that are part of each student's life can come into play.

One might argue that while we are recognizing difference, it appears that we are also losing the possibility of a critical perspective. I think that this is mistaken. Du Bois is the last to accept an uncritical stance. From his view, awareness of issues is the first step to assessing the circumstances and taking seriously a commitment to the gifts each person has to offer. For whites to critically assess the role of whiteness in learning is not some process of guilt assignment, but rather a genuine effort to see the ways in which race affects one's self and the process of teaching and learning. To adopt the sort of position advocated by Du Bois is to come to focus on the possibility of individual grow th, the equality and value of individual gifts. To critically assess the role of racial identity in general and the role of "whiteness" in particular with respect to gifts is to discover ways in which some gifts are suppressed and undermined and, in so doing, find ways of changing the situation. To critically engage the general theory of race and conceptions of blackness, brownness, and American Indianness is to find ways to enrich the process of learning for all students. When issues of race are attended to, faculty and students can more directly avoid the behaviors that 
block the development of gifts and actively (and even at times passively) structure relations in a way that respects individual identities and their gifts to come.

The place of race in learning is complex, but in light of Du Bois's approach several concluding observations can be made. First, if race, at least race of the sort understood by Du Bois, is taken seriously, then it will conserve distinctiveness, not as strictly individual distinctiveness, but as shared difference informed by a history and place, one always growing and transforming. Second, if taken seriously, what we learn from attention to race is how it is to see the world from other perspectives-for those interested in the pursuit of truth, it is to see the world more truly. Third, race in the context of education provides a context in which to understand the moments of human flourishing and the moments of human suffering. To listen to one another across racial difference is to see problems as they are experienced and so to be able to address them. Fourth, making race an integral part of learning is to have a context for self-discovery and critique. To see the ways in which being white in early-twenty-first-century America affects the qualities and possibilities of my life will lead me to better understand the ways in which my identity is formed and undermined by racial oppression.

The University of Oregon mission statement calls for equality and individuality in a context of diversity. What we can learn from Du Bois is that equality amounts to equality of recognition of difference of individuals both as they are located in the world and as they embody race. If we are obliged to do anything with respect to race, it is to recognize its pervasive character, its consequences, for good and evil, and its transformative possibilities. In the end, democracy depends upon such education. In the conclusion of his 1946 assessment of the place of Africa in the developing postwar world, Du Bois concludes with this "message":

Reader of dead words whewould live deeds, this is the flowering of my logic: I dream of a world of infinite and invaluable variety; not in the laws of gravity or atomic weights, but in human variety in height and weight, color and skin, hair and nose and lip. But more especially and far above and beyond this, in a realm of true freedom: in thought and dream, fantasy and imagination; in gift, aptitude, and genius-all possible manner of difference, topped with freedom of the soul to do and be; and freedom of thought to give to a world and build into it, all wealth of inborn individuality. Each effort to stop this freedom of being is a blow at democracy - that real democracy which is reservoir and opportunity.... There can be no perfect democracy curtailed by color, race, or poverty. But with all we accomplish all, even Peace. (1946, p. 261)

\section{NOTES}

An earlier version of this essay, entitled "Race and Learning," was given as a Black History Month address at the University of Oregon, 23 February 1998. 
1. From the University of Oregon Bulletin, 2002-3, http://darkwing.uoregon.edu/ uopubs/bulletin/welcome index.shtml.

2. See Appiah (1990a), for example. Also see Zack (1998) for an excellent survey of the various theoretical approaches to understanding and responding to race.

3. When Cornel West spoke at the University of Oregon, he told the story of Casper Weinberger's comment on Colin Powell: "When I look at Powell," Weinberger said, "I see a man." West asked: "What do you think that Colin saw?" African Americans, West stated, have developed the ability to see race without losing track of humanity. "What Colin saw," West concluded, "was a man who is white."

4. The classification of Du Bois's work is controversial. Some claim that he adopts an existentialist framework (Lewis Gordon 1997); others argue that he should be seen as Hegelian (Zamir 1995). Of course, Du Bois's work is large and complex enough to sustain a variety of interpretations. Nevertheless, a strong case can be made for Du Bois as part of the pragmatist movement that began in the late 1890 s with the work of William James. Du Bois was a student of James at Harvard at the time James was completing The Principles of Psychology (1890). Du Bois mentions James's influence many times in his published work including his final autobiography written in the 1950s. Here he writes that his initial study of philosophy at Fisk University "eventually landed me squarely in the arms of William James of Harvard, for which God be praised" (1968, p. 127). And it was James, Du Bois says, who "guided [him] out of the sterilities of scholastic philosophy to realist pragmatism" (133). Du Bois's earliest work appears to be influenced by historians such as Albert Bushnell Hart, black activists and theorists such as Alexander Crummell, and social researcher/reformers such as Jane Addams. Du Bois's early study of the black community in Philadelphia, The Philadelphia Negro (1899), in fact, was modeled on a pragmatist-framed study by Addams and her colleagues entitled Hull House Maps and Papers: A Presentation of Nationalities and Wages in a Congested District of Chicago, Together with Comments and Essays on Problems Growing out of the Social Conditions (Addams et al. 1895). Most importantly, his work over his long career is focused on the reconstruction of American society in ways that parallel the efforts of Addams and Dewey and are compatible with the kind of transformative pragmatism recently discussed by Michael Eldridge (1998) and Etin McKenna (2001). His work is also consistent with what I have argued are the central commitments of classical pragmatism (Pratt 2002, chap. 2).

5. See Zack (1994) for a good example of this argument.

6. This view is implicit in the work of Appiah (1990b), and long a part of anthropological views of race of the sort made prominent by Franz Boas in the early twentieth century. See Boas (1940).

7. Here the "ideal" marks the end of the need for the active conservation of races, but not the end of difference, since the ideal of "brotherhood" involves the expectation of both continued diversity among peoples and their mutual support as members of a wider "family."

8. James introduces the idea that selves as known are complexes made up of what he calls a material self, a social self, and a spiritual self. The view roughly anticipates Du Bois's notion of the self in The Souls of Black 
Folk. Much of the social theory of George Herbert Mead, Josiah Royce, Jane Addams, and John Dewey can be seen as predicated on adopting a version of James's notion of the self. See James (1890, chap. X; 1892, chap. XII).

9. See Du Bois's essays "The Damnation of Women" and "Of the Ruling of Men" in Darkwater (1920), as well as The World and Africa (1946), and many of his essays in Du Bois Speaks (1970a, 1970b).

10. His approach is not unlike Dewey's idea that education needs to be framed around the particular needs and circumstances of students and their communities. See Dewey (1938).

\section{WORKS CITED}

Addams, Jane, and other residents of Hull House. 1895. Hull House Maps and Papers: A Presentation of Nationalities and Wages in a Congested District of Chicago, Together with Comments and Essays on Problems Growing out of the Social Conditions. New York: Crowell.

Appiah, Anthony. 1990a. "Racisms." In Anatomy of Racism, ed. David Theo Goldberg, pp. 3-17. Minneapolis: University of Minnesota Press.

- $1990 \mathrm{~b}$. " 'But Would That Still Be Me?' Notes on Gender, 'Race,' Ethnicity, as Sources of "Identity." Journal of Philosophy 87, no. 10: 493-99.

Boas, Franz. 1940. Race, Language, and Culture. New York: Macmillan.

Dewey, John. 1938. Experience and Education. In Jo Ann Boydston, ed., The Later

Works, 1925-1953, vol. 13. Carbondale: Southern Illinois University Press, 1981-90.

Du Bois, W. E. B. 1897. "The Conservation of Races." In Writings, ed. Nathan Hug-

gins, pp. 815-26. New York: Library of America, 1986.

. 1899. The Philadelphia Negro: A Social Study. With an introduction by

E. Digby Baltzell together with a special report on domestic service by Isabel

Eaton (New York: Schocken Books, 1967).

. 1903. The Souls of Blatk Folk. In Writings, pp. 357-547. New York: Library of

America, 1986.

___ 1920. Darkwater: Voices from within the Veil. New York: Dover, 1999.

—. 1929. "Shall the Negro Be Encouraged to Seek Cultural Equality?" In Du Bois

(1970b), pp. 47-54.

- 1940. Dusk of Dawn: An Essay toward an Autobiography of a Race Concept. In

Writings, pp. 549-793. New York: Library of America, 1986.

- 1946. The World and Africa. New York: International Publishers, 1965.

—. 1955. "Two Hundred Years of Segregated Schools." In Du Bois (1970b),

pp. $278-84$.

. 1968. The Autobiography of W. E. B. Du Bois. New York: International Publishers. 1970a. Du Bois Speaks: Speeches and Addresses, 1890-1919. Edited by Philip S.

Foner with a tribute by Martin Luther King, Jr. New York: Pathfinder.

- 1970b. Du Bois Speaks: Speeches and Addresses, 1920-1963. Edited by Philip S.

Foner with a tribute by Kwame Nkrumah. New York: Pathfinder.

—. 1971. W. E. B. Du Bois: A Reader. Edited by Andrew Paschal with an introduction by Arna Bontemps. New York: Collier Books. 
Eldridge, Michael. 1998. Transforming Experience: John Dewey's Cultural Instrumentalism. Nashville: Vanderbilt University Press.

Gordon, Lewis R. 1997. "Introduction: Black Existential Philosophy." In Existence in Black: An Anthology of Black Existential Philosophy, ed. Lewis R. Gordon (New York: Routledge, 1996).

James, William. 1890. The Principles of Psychology. 2 vols. New York: Dover, 1950.

- 1892. Psychology: The Briefer Course. New York: Henry Holt.

McKenna, Erin. 2001. The Task of Utopia: A Pragmatist and Feminist Perspective. Lanham, Md.: Rowman and Littlefield.

Pratt, Scott L. 2002. Native Pragmatism: Rethinking the Roots of American Philosophy. Bloomington: Indiana University Press.

Zack, Naomi. 1994. "Race and Philosophical Meaning," The American Philosophical Association Newsletter on Philosophy and the Black Experience 94, no. 1: 14-20.

- 1998. Thinking about Race. Belmont, Calif.: Wadsworth Publishing Company.

Zamir, Shamoon. 1995. Dark Voices: W. E. B. Du Bois and American Thought, 18881903. Chicago: University of Chicago Press. 